\title{
Some reflections on Romanian translation studies
}

\author{
Magda Jeanrenaud* \\ Faculty of Letters, "Alexandru Ioan Cuza" University, Bd. Carol I 11, 700506 Iaşi, Romania
}

\begin{abstract}
Article info
History:

Received June 1, 2015

Accepted June 18, 2015

Published July 17, 2015

Key words:

translation studies

translation practice

central language

peripheral language

symbolic field

globalization

Abstract

In this paper, I decided to examine two "verdicts" on the specificity (or the lack of specificity) of Romanian translation studies in order to define and explain the present situation in this field: one given in the Encyclopedia of Translation Studies, the other in a book on "Romanian translation ideas and meta-ideas". I believe that the current situation justifies the following hypothesis: the current specific of translation theories in the Romanian space is entailed by the existence of two circuits. The first is academic and international, aiming at including the Romanian research in European directions, by assimilating them more or less. The second is a national circuit - where the positions expressed within the first circuit penetrate indirectly, through "central" languages—and it manifests itself as selective and elective affinities between the two; their interaction is sporadic and it occurs mainly through other languages, not through an interiorization process related to the language of the Romanian source space.
\end{abstract}

"One should never pass over in silence the question of the tongue in which the question of the tongue is raised and into which a discourse on translation is translated". ${ }^{1}$

Jacques Derrida

\section{Introduction}

There is a significant difference in the project of approaching translation studies issues between the first and the second edition of the famous Encyclopedia of Translation Studies (the editions of 1998 and 2009). Within their argumentation for the necessity of a new edition, but also to reflect the interests and priorities of a scientific community that had evolved and consolidated in the meanwhile, the volume editorsMona Baker and Gabriela Saldanha-seem to have realized only after starting editing it (as hinted in the Introduction) that "Translation Studies has traditionally been strongly Eurocentric in orientation, and in some parts of the world continues to be dominated by theoretical paradigms that originated in the West and that are oblivious to the rich and substantially different experiences of translation outside Europe and North America" (Baker \& Saldanha, 2011). In the editors' opinion, considering that this discipline has become an independent academic field of study, more attention should be paid to the increasing interest for approaches outside the two cultural spaces in order to "reconsider the scope and central preoccupations of the discipline" and to determine a new balance, which must also include "voices" from the Asian (mainly Chinese), African, and-in the words of the two editors-the Middle East space (a formula used in the two volumes edited by Theo Hermans, titled Translating Others; Hermans, 2014). In other words, the new edition aimed at presenting translation studies in the light of an increasingly obvious "growing multidisciplinarity" and at considering its apparent tendency of breaking "away from its exclusively Eurocentric origins".

In my opinion, however, the concept of "Eurocentrism" should have also been carefully and thoroughly reconsidered, in order to reinstate its richness and variety: whereas, within the European field,

*Email address: mjeanrenaud@hotmail.com.

${ }^{1}$ Derrida (1998, p. 204). 
Magda Jeanrenaud

influence networks and symbolic power fields are structured around the "great" cultures, disseminated by "central" languages, one should also examine the reactions to translation and the reflection surrounding it emitted by "small" cultures and conveyed by "peripheral" languages. In other words, this space is far from homogeneous; furthermore, it is crossed by uneven tensions, which depend largely on the "great" cultures conveyed by "central" languages, depending on which "small" cultures conveyed by "peripheral" languages position themselves through various configurations, not always obedient. By labelling them "invisible minorities" (Cronin, 2003, p. 139 sqq.) and comparing them to... Count Dracula (a Romanian mythological character) - who looks at himself in the mirror, but can never see himself-, Michael Cronin had underscored, a few years earlier, the speakers of what he calls "minority languages", which have failed to see themselves in the mirror of translation studies. Indeed, the 1998 edition of the aforementioned dictionary fails to mention the "translation and minority languages" or any theoretical approach to this issue, which is all the more paradoxical as precisely the cultures developed by "minority" languages are translation cultures par excellence. On the other hand, numerous researchers have been inquiring-by extending it to the geographic spaces where English dominates-whether the concept of Eurocentrism is "at all useful" and whether it should be "considered theoretically redundant" (van Doorslaer \& Flynn, 2013, p. 5; Flynn, 2013b, p. 61-77).

Concerning the Romanian translation studies tradition, the late Janos Kohn-who did not get the chance of presenting it within the second edition-formulated in the edition of 1998 a succinct, maybe insufficiently argued verdict (also explicable by the limited space allotted by the Encyclopedia to the various "traditions"), but which deserves to be presented in detail. Author of a successful work on the compensating virtues of the Romanian language in translation (Kohn, 1983), Janos Kohn formulates, in the "History and Traditions" section, the following diagnostic on the specificity of Romanian translation theories: "Translation theory remains closely connected with practice in Romania" (Kohn, 1998, p. 539). His diagnostic is supported by the significant amount of translations done in the post-war period, which also explains - in his opinion-the obvious correlation between theoretical studies and practical achievements. He also underlines that such theoretical texts often pertain to professional translators; however, he argues the idea by citing the opinions of illustrious Romanian writers, also renowned for their translations (Blaga, 1957; Doinaş, 1965). However, Kohn does mention the existence of academic works focusing on linguistics-centred translation perspective, but he also emphasizes that "the number of published books on translation remains relatively small” (Kohn, 1998, p. 540).

Recently, a study has been published on "Romanian translation ideas and meta-ideas" (Lungu Badea, 2013), where the diagnostic is different from Kohn's, though not less categorical. In the chapter on "current orientations", which focuses on the "post-1989" period (the past 25 years), Georgiana Lungu Badea pinpoints, first, the strong impulse provided to Romanian translations by certain "international cultural institutions and by the globalization trend"; in her opinion, they would have triggered-as a boomerang effect-a process of "critical apparatus regulation" (Lungu Badea, 2013, p. 125), used by translation theories. The author includes, among them, the works of researchers of Romanian origin, but who have studied and worked in different academic settings abroad (Ioana Popa, Ecaterina Cleynen-Serghiev, Iulia Mihalache). However, Lungu Badea has a firm opinion about a potential specificity of Romanian translation studies: "Though we cannot speak about a tradition of the rigorously theoretical discipline of Romanian translation studies, the theoretical contributions of Romanian researchers-translators and linguists alike-are numerous and diverse" (p. 109). Subsequently, the author rhetorically questions, explicitly and slightly late (p. 132-133) ${ }^{2}$, the operational capacity per se of a concept such as "Romanian translation studies".

The two verdicts-expressed in an equally convincing manner by both researchers concerning the specific or non-specific of Romanian translation studies - are separated by at least one decade and a half. During this period, the academic side of translation studies has extended massively and rapidly, in the

\footnotetext{
${ }^{2}$ The title of the previous chapter, "Orientări în cercetarea traductologică românească”, thus becomes paradoxical.
} 
entire Romanian higher education and at all its levels (bachelor's studies, master, doctorate, ample research projects). It has managed to captivate more and more categories of specialists: it is apparent in both the considerable number of volumes and studies published by them in this period, and the emergence of at least two journals dedicated exclusively to it. If we were to agree with the two opinions, we may deduce that the extension and consolidation of the domain would have failed to determine the consolidation of a national specific, and that it would have actually undermined the one of the $90 \mathrm{~s}$, by diluting it during a "globalization" process of research. On the other hand, I still fail to understand clearly what the author means by its "critical apparatus regulation". As I illustrate in the following pages, insofar as most works that use it are written in other languages than Romanian, this process has yet to occur.

In order to examine the underlying arguments of the two standpoints, I chose two moments in the Romanian thinking that I considered particularly fertile regarding translation, both before 1989, for a further comparison with the post-1990 situation.

\section{The ' 60 s of the $20^{\text {th }}$ century}

In the'60s, the publication in France of the work Problemes théoriques de la traduction - written by Georges Mounin (yet to be translated into Romanian) - stirred a heated debate concerning the role of theoretical thinking on translation, published in the renowned journal "Secolul XX", in two consecutive issues ( 1 and 2 , from 1965). In both issues, several personalities of the cultural life of the period posited on the work of the great French linguist and translator, but not all of them had benefited from a solid philological training. The debate included eclectic personalities of the Romanian cultural life, such as Marcel Breslaşu, a poet, fabulist, composer, lieds composer, musical chronicler, lawyer, translator, and editor-in-chief of "Secolul $\mathrm{XX}$ ” for a few years, where he published several translations; a complex personality, a poignant mixture of light and shadows (Șerban, 2011).

The second text belongs to Jacquier $(1965)^{3}$, the one who accused Roland Barthes for losing his French citizenship, thus being forced to continue his life and career in Romania until his death (1980; see Matei, 2014). Author of a PhD thesis in linguistics, a high school and then university teacher, specialized in the field, Jacquier has an atypical standpoint among the voices who comment on Mounin's book, though he begins by stating the "difficult" work of translators, who have to be "both good readers and good writers". However, he pinpoints categorically that "the group of scientific and technical contents or languages [...] is fully translatable into all languages of the world", because this group contains "univocal utterances", not "affective expressions", and "the intellectual structure of the man is the same on all meridians, though expressed differently" (Jacquier, 1965, p. 153), statements that reveal a French-origin belief in the universality of the human spirit.

However, instead of examining the linguistic postulates and their incidence in the translation issue, Jacquier uses an enflamed essayistic indictment against linguists and their new theories (he also disapproves the-mostly Saussurian-structuralism, the Bloomfieldian behaviourism, Hjelmslev's glossematics, Harris's distributionalism, or the Neo-Kantians like Cassirer; this shows that he was aware of those currents). He posits that, "instead of encouraging" the work of translators, these theories only "condemn it to silence" (Jacquier, 1965, p. 155), as if they only wanted the man to "remain trapped in the solitude of self-limiting individual, a designated victim of the fear of inexpressible" (p. 155). Captivated by his own essayistic style, Jacquier continues in the same register, by invoking constantly the translators, who are "indifferent" to the validity or caducity of linguistic theories (p. 155): hence, in his view, theory becomes not only useless, but also harmful. The only aspect worth highlighting is the de facto existence of translations and the superiority of translators' activity. Jacquier does not make the difference in terms of level between theory (which he considers suspicious) and the practice per se (translators are condemned to accomplishing their civilizing mission while menaced by linguistics, which would only aim at "making [their] work as hard as possible" (p. 157).

\footnotetext{
${ }^{3}$ In 1991, Mircea Muthu edited a volume under the same title, at the Dacia press of Cluj-Napoca.
} 
However, the author unconditionally accepts the validity of translation impossibility theory when it comes to poetry. In this case, in his opinion, only bilingual editions could help the reader discover the essence of the source text; furthermore, such editions should comprise a "portrait" of the source language (with details on its phonetics, spelling, and grammar) and as many explanatory notes "as possible", accompanied by multiple sequential translations (p. 160). Moreover, he does not miss the chance of mentioning the translators' ethics. He enumerates the qualities of good translators, once they "have accepted that literary translation is but an approximation effort" ${ }^{\text {" }}$ : probity, modesty, and the pride of a profession that contributes to "the intellectual development and to the spiritual delectation of thousands and thousands of people, as well as to the moral closeness of peoples" (p. 160); in a word, to the constitution of universal literature. Above all, translators must continue their civilizing mission "without being troubled by verdicts pronounced by certain linguists or by the sirens of the absurd and their harmonious complaints on the fear of ineffable, the loneliness of individual consciousness lacking communication with other, and the eventual inevitable failure of languages" (p. 160).

In the following issue of the journal, Nicolae Argintescu-Amza-literary critic, essayist, sociologist, philosopher, fond of plastic arts (author of a book about Vermeer and one about the Romanian painter Grigorescu), aesthetics and psychology, art chronicler, translator into Romanian of Shakespeare, Horace, Lucretius, Baudelaire, Schiller, Molière, Claudel, Mayakovski, Pavese-attacks Mounin's “ease”. He posits that Mounin's ease is obvious from the title of his first book, and that he had been trying to compensate it afterwards by an "opposite excess", by dedicating "excessive attention to issues concerning exclusively the modern philology, by using too many doctoral frameworks" (Argintescu-Amza, 1965, p. 157). That provided the occasion of regretting the "formalism" of "most linguistic research" (p. 157) and of launching a diatribe toward its excesses, of fearing that a "false linguistic interpretation of the translation process" may postpone "by many years to come the elucidation of this extraordinary means of global culturalization" (p. 158), which is translation. Or, "the elucidation" he mentions should be left to psychology, which is entitled to determine "the mental levels", or the translator's skills, because the latter has the right to produce, like Arghezi, "translations that outclass the original" (p. 159). All in all, Mounin's unpardonable sin remains that "the potentially fundamental principle of the translation process was not even mentioned" (p. 160): translation is an interpretative act. As such, the author counsels, it would be better to "overcome the fallacious specificities of fixity", "obvious coquetries of a certain linguistic 'philosophizing"” (p. 160), and to "overcome the false scientific apparatus" (p. 161). Briefly, the author mentions the necessity of a work entitled "Practical issues of the art of translation", without "narrow technicalities", because-and he considers it a last warning - in "research aiming at scientific objectivity", "the irrational excess of purism" is not only "infertile", but it can also "lead the mind astray" (p. 163).

To the texts of the two aforementioned authors, I add a third, often invoked in the present, too, signed by the poet, essayist, and translator Ștefan Augustin-Doinaș, renowned for his translation of Faust by Goethe, Hölderlin's poems, and of texts by Mallarmé, Paul Valéry, Martin Buber, Giovanni Papini, etc. (he is believed to have translated from more than ten languages!). As visible from the very title, Augustin-Doinaș makes a solid apology-consolidated by an argumentation with references to several western theoretical sources - for "the possibility" of translation: his text ends by his wise invite addressed to translators, of "proving practically that 'the miracle' of poetic translation exists", and of leaving "to others" "the explanation and theoretical grounding, of [its] possibility" (Doinaş, 1965, p. 167).

For these cultural personalities who occupied various positions in the Romanian symbolic field of the period, but who all benefited from "visibility", Mounin's book is more of a pretext to give sentences on the quality of translations, on editorial plans, than to speak on the need of developing the theoretical thought on translation in the Romanian space. Breslaşu (1965) admits the lack of interest for theory, but he does mention it in his conclusion-more like a courtesy, actually-and he underscores that he considers translation theory an "adjuvant" for the person who wants to engage in the "vast and complex

${ }^{4}$ In a different period, Paul Ricœur among others would speak of "equivalence without adequacy". 
field of universal literature" (p. 150).

Therefore, the Romanian tradition in translation studies seems to have developed within a recurrent theme of the type "how I translated the..." (an allusion to Blaga, 1957), "interpreting..." (Porumbacu, 1951), and "the art of translating" (starting with Vianu, 1956, or Cassian, 1981). It is no surprise that the reflection on translation was considered part of comparative literature, of aesthetics, or history of literature, taking into account that the English formula Translation Studies and the French traductologie had not been coined yet. However, it is worth underlining that all those who commented on Mounin's book-writers, translators, or linguists, with all their updated readings-expressed both their scepticism on the role of linguistics (and of theory in general) in the thought on translation and their interest for translation practice with all its components. However, they were interested only in literary translation, and they simply ignored the translation of other types of texts: they did not consider the latter translating, but transposing mechanically certain terminologies ${ }^{5}$.

\section{The ' 80 s of the $20^{\text {th }}$ century}

In the first part of the '80s, several events directly related to the reflection on translation theory occurred, and they were all comprised within just a few long-run publications. Therefore, in June 1980, a great National Colloquium on Translations and Universal Literature was organized. The stenograph of the works was published one year later, in 1981, in a special issue of the journal "Viața Românească", edited by the Writers' Union. Afterwards, in 1983, the first issue of an equally renowned journal of the time- "Cahiers roumains d'études littéraires" - was dedicated exclusively to the theme Poïétique/Poétique de la traduction. Also in 1983, the aforementioned work of Ioan Kohn was published (Kohn, 1983); two years prior, in 1981, Orizontul traducerii by Gelu Ionescu had been published (Ionescu, 1981a), which comprised a very consistent introductory text, equally valid today.

Though the theory had just been granted a specific name (in the years 1972-1976) and the texts that I invoked earlier in an attempt to delimit the centres of interest in the '80s show a good correlation of autochthonous reading with synchronic writings and publications of the European space, the focus remains the issue of the target text fidelity toward the source text within language couples. The underlying cause is the same mistrust in linguistic approaches and, by reflection, the underscoring of various types of errors comprised in the translation process. This is somewhat understandable concerning the opinions expressed by the participants to the National Colloquium on Translations and Universal Literature-most of them translators, but it is also apparent in case of the texts published in CREL 1983, which comprised many studies signed by academic researchers.

Ioana Popa suggests a possible explanation for most debates focusing on the theme of freedom and/or fidelity in translation: she has pinpointed the same particularities in the Soviet space and then in the entire East-European area. Considering that many forbidden writers were authorized to sign and publish translations, Popa posits that they may have seen this activity as a "creative opportunity, which may have influenced their translation practices" (Popa, 2013, p. 28). Therefore, they may have been, so to speak, congenitally prone to free translation; on the other hand, the same author points out that such debates were-at least in the '30s- "politicised" in the Soviet space, and that "the official preference for free translation has been interpreted by some researchers as having facilitated censorship and intervention on source texts" (p. 28). In other words, though the discussion on the weight of the two texts within the translation process may have been troubled by conflicting trends and influences, translators tended-out of subjective and ideological reasons - toward valuing infidelity. In my opinion, this argumentation does not apply to the Romanian space, at least not during the periods in question ((Ionescu, 1981b, p. 36) $)^{6}$. Most authors

\footnotetext{
${ }^{5}$ Argintescu-Amza (1965, p. 162) states that "[...] nor the colportage translation of technical or vulgar vulgarization texts can have anything to do with artistic translation". Storch (1981, p. 72) anticipates "the important role of computers", which "will translate very well scientific text based on notions and equations".

${ }^{6}$ The author also mentions the phenomenon, but he limits it to the period 1945-1965, when "many writers did not
} 
who have chosen this topic are categorically in favour of the fidelity criterion; furthermore, they have been questioning the poets' ability of transposing the great poetical texts of universal literature: Tudor Arghezi's translations, for instance, are marked by his "too strong poetic personality", which prevented him from "understanding the spirit of a foreign author" (Covaci, 1981, p. 14).

However, it is worth mentioning a few different voices, such as the one of Alexandru Balaci-who wished for a translation aesthetics that "proposes to elucidate [...] the essence of the translator's translation work" (Balaci, 1981, p. 74) — and mostly the one of Gelu Ionescu. The latter complains about the lack of a consistent theory, which would also explain-in his opinion-the amateurism of translation practice per se. For the first time, somebody argued intensely for the need of theoretical developments, while viewing the "inexistence of theoretical publications" as a "consequence of the same traditional mindset that patrons most of our translators" (Ionescu, 1981b, p. 89). A few lines later, the author insists upon and he states the necessity of theory as formative instrument of practice, too: "we cannot afford not stimulating a heavily theoretical activity regarding translation issues" (p. 89). It could also be stimulated by translating such texts, which would constitute the framework necessary for overcoming this "astonishing traditional stage" (p. 89), as well as by developing "theoretical, scientific, professionalized consciences" (Ionescu, p. 89-90) in this direction. To this end, he also militates-by associating to other voices (Verzea, 1981, p. 50; Lăzărescu, 1981, p. 94; Eliade, 1981, p. 94) -for the necessity of translation criticism, which had not even been outlined (not only in the Romanian space), and which should exceed the canons of initial criticism and to conduct a genuine technical analysis, "applied to the finest details of a translation" (Ionescu, 1981a, p. 52; 1981b, p. 89). The author supports the same ideas, by developing their basis, in the preface to his book on "translation horizon", but where the reflection on it is included within the history of contemporary Romanian literature, from where-in his opinion- "it is almost entirely absent"; practically, it is considered a mere "annex of the original literary phenomenon" (Ionescu, 1981a, p. 9). According to him, two research directions may contribute to reconsidering the position of translations: examining their reception in the Romanian culture and elaborating a theory of reading (p. 11-15). From such a perspective, for instance, the phenomenon of "late" translations could also explain the way in which the original literature "re-assimilates" the past, by preparing new orientations or by consolidating and intensifying others, which are incipient. The author reprises the idea of the necessary translation theory, which he considers a chance given to translators of acquiring a "superior theoretical conscience" (p. 29).

The continuity element, which I consider the specific of the Romanian reflection and which links the two moments extrapolated above, is the clear delimitation from theory and, as stated before, the resistance to it, viewed with suspicion. This feature also "spared" the Romanian reflection from reconsidering in any way the "mirage" of linguistics, which determined so many reconsiderations in the west European space, but which also made possible the construction of translation studies as an autonomous approach. At the same time, the reflection on practice is superior-both quantitatively and qualitatively-to the reflection on theory, as it also results from what Irina Mavrodin coined and attempted to constitute, as early as the '80s, a "practical theory" (Mavrodin, 1983).

It is nonetheless true that this "specific" developed on a fertile field: in the Romanian space, an impressionist, essayistic tradition has significantly marked the reflection on literature (its climax was Istoria literaturii by George Călinescu), which determined-more than once-the purely theoretical attempts to self-justify. Therefore, it is worth highlighting — and this is proven on the long run-another rather paradoxical situation. On one hand, the authors of the aforementioned texts (and of many others that I did not have the space to analyze here) were aware of the works on translation studies written in languages of circulation; they showed no sign of misinformation. On the other, the writers, essayists, poets, and specialists showed caution and reticence and sometimes they refused explicitly to admit the necessity of constructing a theory. Even CREL 1983, where many "university personalities" share their thoughts,

publish—or they published just a part of-what they wrote, reason for which they began translating: a 'positive' effect of a regrettable situation". 
focuses on the same hermeneutic confusion between practice, experience, and theory. Irina Mavrodinin charge with this issue and the author of the first text, who also more or less sets the direction of the discussions-begins by stating "Une bonne traduction ne saurait jamais être le résultat de l'application mécanique d'une théorie, fût-elle la plus adéquate, parce que la théorie, de par sa généralité, sapplique malaisément à la traduction [...]. La traduction est, avant tout, une pratique [...]” (Mavrodin, 1983, p. 4), as if theory and practice had the same purpose!

Therefore, translation is correlated with literature itself and the issues of literality and fidelity occupy again the central role in the debate; theory is compelled to provide a contrastive and stylistic sentence: Victor Ivanovici declares that "naturally I adopted the method of the contrastive approach linguistic stylistics [...]" (Ivanovici, 1983, p. 11). His decision came after concluding, not necessarily as a positive event: "the theoretical bibliography on translation has proliferated dramatically" (we are talking about the '80s!); he enumerates at least three types of "often disagreeing" theoretical approaches (Pop-Corniș, 1983, p. 34). Moreover, Marcel Pop-Corniş proposes to "estimate the extent to which they have affected the Romanian theory and practice of translation, and even more dramatically, the translation of Romanian poetry in languages of circulation" (p. 35-36), only to conclude that they play a (negative) role insofar as they influenced the Romanian poetry translators on trying "to do justice to both form and idea". This indecision alters the entire translation, and it often provokes "the opposite effect" (p. 41) upon the reception.

The theme of Romanian literature reception in the West is recurrent and sometimes it includes nationalistic hues: its inclusion in the global circuit depends on realizing that "the criterion of universality is forced to depend upon that of translatability" (Pop-Cornis,, 1983, p. 36). Numerous voices argue for a translation in tandem (Eliade, 1981, p. 93; Ralea, 1981, p. 86), a Romanian translator and a translator who is a native speaker of the target language; there are many studies and opinions on the analysis of translations of Romanian literary texts into languages of circulation ${ }^{7}$, though some labelled them as mere "propaganda abroad" (Munteanu, 1981, p. 60). In this case, too, just like concerning translations into Romanian, the general opinion does not favour free translation and it does not view writers and poets as the most suitable translators (Covaci, 1981, p. 14). In this sense, Leon Levițchi invokes-when given the floor-a "Shakespeare committee", founded in 1950, which included great personalities of the Romanian culture, which "legalized certain Romanian standpoints on the fundamental obligations of honest translators". It was unanimously approved by the Writers' Union, and at least seven points concerned the following "norms": the translation shall be integral, it shall be made from the source language, it shall not "overbid",

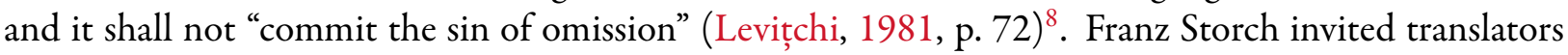
not to see in translation "a beauty that shines through its infidelity" (Storch, 1981, p. 72); Alexandru Balaci assimilates the art of translation to fidelity; in his opinion, the task of the translator is to render "as accurately as possible [...] to transmit the integral content [...]" (Balaci, 1981, p. 73-74), and the list of people with similar opinion is significantly longer.

\footnotetext{
${ }^{7}$ Colocviul național de traduceri și literatură universală concludes as follows: all participants are willing to do what is necessary in order to disseminate the Romanian literature in the world. Most of the 42 people who took the floor (Aurel Covaci, p. 16; George Potra, p. 19; Edgar Papu, p. 20; Lörinczi Làszlò, p. 22; Tatiana Nicolescu, p. 25; Constantin Crișan, p. 29; Corneliu Barborică, p. 31; Andrei Brezianu, p. 39; Maria Banus, p. 42; Florin Murgescu, p. 45; Petre Solomon, p. 49; Ileana Verzea, p. 50; Cristina Petrescu, p. 52; Balogh Iózsef, p. 53; Florian Potra, p. 56; Romul Munteanu, p. 60; Dan Grigorescu, p. 65; Ștefan Augustin-Doinaș, p. 68; N. Carandino, p. 71; Franz Storch, p. 72; Alexandru Balaci, p. 4; Radu Lupan, p. 76; Paul Alexandru Georgescu, p. 77; Cristea Chelaru, p. 82; Alexandru Paleologu, p. 84; Catinca Ralea, p. 87; Zor DumitrescuBușulenga, p. 90; Marin Mincu, p. 92; Irina Eliade, p. 94; George Lăzărescu, p. 95; Iulian Neacșu, p. 97; Micaela Slăvescu, p. 99; Andrei Bantaș, p. 104) expressed such a desire.

${ }^{8}$ In the same issue, when discussing translation errors, many others (e.g., Busuioceanu, 1981, p. 62, etc.) implicitly invoke the desideratum of fidelity and rigour in translation.
} 


\section{After 1995}

The historical, ideological, and political post-1989 fracture radically altered the idea of continuity, and it even entailed a refuse of adopting any tradition. At the same time, after 1995, translation studies began an institutionalization process: around 2000, translation studies sections were constituted in all higher education institutions, as part of bachelor studies. Afterwards, specialized masters in translation studies and interpreting emerged, which determined the elaboration of numerous graduation papers and master theses in this field. The number of doctorates within translation studies field multiplies every year (though the admission procedure to the Doctoral Schools and the first-year courses-comprising two modules, literary and linguistic; the PhD candidates who chose translation studies themes for their thesis mainly opted for the linguistic modules-accept only tacitly a strict translation studies specialization). Most colloquia and events of a "generalist" or philological nature comprise sections dedicated to translation studies. Furthermore, a couple of journals dedicated exclusively to reflection on translation were constituted, and they have acquired a certain reputation in the symbolic field. The research - stimulated by several European and national research projects-started including scientist teams, which contributed to their specialization in the field. Ideas no longer circulate only through books; direct contacts multiply by the presence in various habilitation committees, doctorates, competitions for functions, but also diverse mobility programmes, such as Erasmus or Ceepus, for both researchers and students. The themes of the previous period (focus on practice, discussion on fidelity, distancing from theory, and militancy for inclusion in the international market) disappeared and they diluted significantly once the translation studies became institutionalized, for at least two reasons. On one hand, synchronization with the European reflection that had already consolidated investigation fields for translation-act and process-, fields that had theoretically become autonomous; their main themes are taken over and studied in new modules and accredited sections within higher education. On the other, an ideological reserve, which emerged after the communist regime collapsed and which generated a mistrust or even lack of interest for the reflection axes of the previous period; sometimes, these axes were simply ignored.

This openness toward the western space engages a change in direction within the configuration of centres of interest and of young researchers' training. The latter have become increasingly interested in the evolution of great theories elaborated in the west, as well as in the most adequate ways of rapidly joining the symbolic field outlined at the "centre". The "fracture" between a "before" and an "after" was intensified by two other elements, with conjugated effect, able to dilute (and even make disappear) certain traditions specific to the Romanian space: on one hand, the globalization process, including in the symbolic field; on the other, the "marginal" position of the Romanian culture and language toward international languages and cultures. This may explain the passage from the "practical theory" tradition-that Kohn coined in 1995 - to the lack of any Romanian specific tradition whatsoever, diagnosed by Lungu Badea (2013). The two opinions are not contradictory, but they simply record two situations generated by two different historical moments. Therefore, the sociological analysis conducted by Gisèle Sapiro-on the composition of world market translation, "asymmetrical" by definition, where the flow of translations moves from the centre toward the periphery from the perspective of the rapport between source and target languages (English has a "hyper-central position", German, French, and Russian a "central" position, some other a "semi-peripheral" position, while the rest, which cover less than $1 \%$ of the translation market, have a "peripheral" position) (Sapiro, 2012b, p. 33) —can also be extended to the circulation of theoretical flows. These flows are also highly influenced by the languages/cultures where they develop, which have been following the same directions, with an almost unique direction: "Globalization has fostered the unification of a world market translation and intensified exchanges, but it has not favoured cultural diversity as measured through the source language of translated books" (Sapiro, 2012b, p. 37). I conclude thatconsidering the explosion of translation studies works- the pressure of the European and Anglo-Saxon "centre" or "centres" occurred without any kind of "resistance" opposed by a native tradition (absent in terms of theory) and that it also entailed the disappearance of the previous specificity (focus on practice). 
Nonetheless, it failed to facilitate the emergence of a new one. There are several explanations for this phenomenon, among which I will synthesize several, which I consider more obvious.

The translation studies sections-misfortunately called, in all Romanian universities, AML (applied modern languages) - provide a double specialization: translation studies and two foreign languages (A and B specializations); therefore, students whose specializations include the Romanian language do not have access to these study programs. Practically, teachers choose whether to include it or not within certain subjects, but there are no structured translation studies. Before the field called Communication Skills reunited diverse practical courses of translation, conversation, editing, there was, for instance, a practical course of interlinguistic translations, where students acquired skills by translating from one foreign language into another, without using their mother tongue.

Theoretical courses-following a tradition began after World War II-are held in the two foreign languages: the student attends (and will be assessed in terms of translation studies) two courses under this title, one in English and the other in French, if these are the two languages studied. Compartmented as such, they create the impression of distinct "French" or "English", or other type of translation studies. Graduation papers, just like master theses, are written and then presented in the main language of study, before a committee. Only the master studies admit students who had graduated from a combination of languages such as English-Romanian; however, at least initially, they will be less prepared than AML graduates will, because the latter already benefit from basic translation studies notions. When it comes to elaborating a $\mathrm{PhD}$ thesis, most candidates choose to write it in the language used during theoretical courses, because it is easier to use the conceptual apparatus. However, many students do not know how to transpose it into Romanian (we refer here to the whole set of language notions acquired throughout the academic years) or they have only approximate ideas in the matter (v. Lungu Badea, 2013, p. 125).

This old tradition of the Romanian higher education system for training specialists in modern languages has never been contested, at least not to my knowledge, all the more as, presently, any alteration would determine a drastic decrease in the number of foreign students who wish to attend the courses of the Faculty of Letters within European exchange programmes such as Erasmus or Ceepus. The irony is that, following the first two sessions, during which candidates were given translations involving only two languages (a foreign language and the mother tongue), the great translation competitions for the European Union-organized by the EPSO (European Personnel Selection Office) based in Brussels-also introduced grammar tests for mother tongues. However, the translation studies graduates from Romania, with a French-English specialization, for instance, did not benefit from a strong theoretical foundation or from communication skills in their mother tongue (except for specialized languages, perhaps) during their university training.

There are two journals dedicated exclusively to translation studies. One of them is published in French, the other in several languages, but never in Romanian: their impact in creating and assimilating conceptual equivalents in Romanian cannot thus play a decisive role. On the other hand, though they are thus included in the international market, they do not benefit from a real circulation on the Romanian market; anyway, they are not very present in the Romanian literary and scientific press?

A very optimistic one, Mircea Vultur's view on the rapport between "cultural globalization" (defined as a process of "spreading cultures all over the world") and what he calls "smaller eastern European societies" results also from the perspective adopted by the Canadian sociologist. He examined the phenomenon from the periphery to the "centre", without trying to solve, beforehand, a set of theoretical contradictions. In fact, he considers the extension of influences from the "centre" toward the "periphery" an inevitable phenomenon, supported practically — not only from the "outside", but mostly from the "inside" - by the current mechanism of eastern European cultural mindsets evolution per se, where "the fear of linguistic Americanization and the domination of English language does not exist as a serious concern” (Vultur,

\footnotetext{
9"Atelier de traduction", a biannual journal of theory and analysis of translation published in French, University "Stefan cel Mare”, Suceava; “Translationes”, a plurilingual journal of translation studies, West University, Timişoara, appears once a year.
} 
2002, p. 195). From this perspective, even his statement on the dissemination of cultures in the world seems misbalanced by the homogenising trend (pinpointed by the same author!) caused by the supremacy of the one disseminated by the English language. Indeed, as the author posits, even 25 years after the collapse of the communist regime, intellectuals still view the State sceptically (p. 195), which lead to devaluing the notion of "collective identity", perceived as a barrier for modernity (assimilated to American cultural hegemony) (p. 197).

This situation reflects massively in the current state of translation studies, as it appears in the statistics of publications. The files of the Central University Library in Iași concerning "translation studies" comprise 176 bibliographic records for the period 1993(5) - December 2014. I classified these records as follows: translation studies dictionaries, original foreign books, foreign books translated into Romanian, books by Romanian authors published in foreign languages, books by Romanian authors published in Romanian, $\mathrm{PhD}$ theses, papers published in journals and periodicals, and books comprising the proceedings of conferences on translations studies. Their analysis emphasizes on several essential features of the current reflection on translation studies in the Romanian space:

1. two dictionaries were published in this period (one of them was reprinted at least twice);

2. the number of foreign books written by foreign authors is very scarce-11 volumes; they make up a very heterogeneous corpus ( 3 German volumes, 4 French volumes and the rest Anglo-American); their presence in the library is probably due to donations;

3. the number of books on translation studies, translated into Romanian, is strikingly small: 7 ( 1 from Greek, 1 from Spanish, 1 from Italian, 1 from French, 3 from English—one of which dates from 1983, After Babel by G. Steiner);

4. 22 volumes in Romanian, written by Romanian authors (reprints excluded) were published in this period;

5. however, there are 50 volumes (reprints excluded) by Romanian authors, written in foreign languages and published by Romanian publishing houses: 1 in Russian, 1 with Cyrillic characters, 1 in Spanish, 1 in Italian, 2 in German, 17 in French, and 26 in English;

6. the volumes were published mainly by small or university publishing houses; some of them are handbooks or manuals for university students (two of them are addressed to pre-university students);

7. finally, only a few authors managed to get translated on the international market: I identified only two authors translated and published in the European space, both by French publishing houses, one also by a German publishing house.

There is an apparent lack of balance between books published in Romanian and books published in other languages, among which English is, by far, the most common. This may lead to simply "taking over" the western traditions without attempting to anchor them in the Romanian culture; this phenomenon also explains the lack of a Romanian conceptual terminology or their fluctuations from one author to another, which means that, thus far, they have failed to consolidate in Romanian. Most authors are professors or university researchers and they prefer to have their books published (sometimes at their own expense) directly in an international language, considering the teaching method of the entire university field of humanities, as well as from a (rather non-realistic) desire of being part of the book market faster. These books do not address to a more general national public; their reception depends strictly on the languages accessible to readers (comprising university personnel, literary critics, or even translation theoreticians). Furthermore, translation studies students consult them only insofar as they know the language; this leads to a significant fragmentation of knowledge, which remains sealed in the language of the book, when it could have been disseminated precisely using the authors' mother tongue, which would have facilitated their inclusion within the national circuit. This fracture also reflects in the field of translators whothough they do have theoretical opinions on translation studies-have become increasingly "invisible", prisoners of their own working languages and benefiting from limited access to texts analyzing precisely their profession: this suggests that their very mother tongue—the target language-becomes increasingly "invisible", too. 
I believe that the current situation justifies the following hypothesis: the current specific of translation theories in the Romanian space is entailed by the existence of two circuits. The first is academic and international, aiming at including the Romanian research in European directions, by assimilating them more or less. The second is a national circuit-where the positions expressed within the first circuit penetrate indirectly, through "central" languages—and it manifests itself as selective and elective affinities between the two; their interaction is sporadic and it occurs mainly through other languages, not through an interiorization process related to the language of the source space.

From this standpoint, it is worth reflecting on the semantic enrichment and of the cultural openness provided by the French language, considering that the English term globalization was translated by mondialisation. Once the French term globalisation was coined, an interesting semantic differentiation became possible: hence, the two terms are not perfect synonyms in French. Considering that the French mondialisation allows antonyms and derived variants (alter - and anti-), it also connotes pluralism, heterogeneity. The excellent prognosis proposed by Oustinoff (2011, p. 153-165) - founded on the current stage of globalization, which is cultural by excellence (Wolton, 2003, apud Oustinoff, 2011, p. 154, 155, 159)is based (since the UNESCO Universal Declaration on Cultural Diversity, 2001) on multilingualism, on the plurality of languages as "the first political reality of the contemporary world" (p. 101). It is the only solution against Eurocentrism and it can save cultural diversity, all the more as, presently, new phenomena occur at global level, related to the transfer of technologies toward developing societies, which, in their turn, start developing and transferring toward other societies; however, this transfer is no longer done using an international language, but "local" languages (p. 168). We are on the verge of getting past the stage when one only had to know English to be part of multilingualism (p. 169) ${ }^{10}$; this was also proven by the Guide for the development of language education policies in Europe, insufficiently discussed in the Romanian public space.

\section{Conclusion}

Before ending this paper, I would also like to share with you a dilemma, both methodological and epistemological, insofar as I find problematic the inside positioning of those who posit—dare I say, in synchronyon the existence or non-existence of a (national) tradition. Maybe the "inside" position of researcherswhen formulating overall judgements-is not only an ideal position for pinpointing the thrusts by which a cultural phenomenon evolves. Because researchers lack a necessary distance in time (only benefiting from the distance in space), they are more prone to using globalizing statements, sometimes caused by a misguided perspective on the investigated acts. In other words, I believe in the epistemological virtues of exotopia-as defined by Todorov (1982) after Mikhail Bakhtin-because I consider it a chance given to hermeneutic knowledge and to the dialogue comprising two ideally equal partners. The dialogue between a subject who came from "outside" and one who came from the "inside"-both with equal skills in the matter-is, in my opinion, the ideal type of debate for topics such as translation studies.

In Iaşi, a festival called FILIT (International Literature and Translation Festival) takes place every year. It has acquired international recognition rather rapidly and, for almost a week, it reunites renowned Romanian and foreign writers, as well as their equally famous translators. The festival includes round tables, discussions among translators, workshops, interviews with writers and their translators, and even conferences on theoretical themes. Maybe it is not a coincidence that, during one of the round tables of the festival, a voice was heard asking why the festival is called "literature and translation", considering that "translation is literature" after all... Beyond the apparent pseudo-joke (that is, if it was meant as a joke), it also reflects a "traditional" resistance to theory-which I have discussed above—and it tenacity, because it pertains precisely to the president of Writers' Union in Romania, known as one of the most important literary critics and the author of a monumental and heavily-discussed Istorie critică a literaturii române [Critical history of the Romanian literature].

\footnotetext{
${ }^{10}$ The (French) elites who have placed their bets only on English, states Oustinoff, are simply one step back.
} 
As if to "excuse" her own belief in the absence of a Romanian translation studies tradition, Georgiana Lungu Badea rhetorically asks whether "it is 'useful' and 'functional' to compartmentalize translation studies into national divisions, whether there is a 'utility' in 'nationalizing' (Lungu Badea, 2013, p. 133; the authors uses quotation marks for this term, sic) classifications on typologies". Anyway, the same author posits that, in this case, we should also ask ourselves whether we can speak of French, German, American, Italian, etc. translation studies. The author also seems to suggest that the orientations and directions specific to a national space are not necessarily part of its specificity, because they do not "exclude the interest" for "other aspects of translation studies research" (p. 134; it is the last paragraph of the work). In my opinion, precisely the interest for "practical theory" was part of Romanian translation studies specificity, just like the debate on fidelity/freedom in the context of the period before 1990. I also believe that they disappeared under the pressure of the "centre" or the "centres", which brought along other themes, relating to which researchers wanted/had to have a standpoint. Just as translations are not "innocent", theoretical approaches can never be fully "neutral", but—as posited by Gentzler (2013)_-deeply implicated in power politics" ${ }^{11}$.

As pointed out by the text of Jacques Derrida, which I used as motto for this paper, no theory is independent from the language it expresses, and one cannot say language without saying culture. It is no coincidence that the Romanian space has failed to provide (yet) a great translation theory: it is also related to the lack of other founding theories, to some kind of mistrust precisely in a theory's ability to facilitate knowledge. This is the reason why functionalist theories developed more in the German space than in the French one: the tradition-harboured by Romance languages-of viewing translation more like a treason has not developed much in the German space, where translation has been associated more with taking over tradition. Maybe this is why the enthusiasm for skopos theory is more visible in the German space: it does not have to fight the suspicion of a transmission focused on textual function alone. Just like the theme of literalism in the French space-exposed by Antoine Berman or Henri Meschonnic-has been related, for more than a century, to a total faith in the beauty of infidelity.

The way in which theories evolve in the field of humanities is, beyond doubt, dependent on the languages and cultures where they develop: they are the products of subjects who depend, in their turn, not only on personal traits, but also on their background and culture. Furthermore, research directions depend not only on an academic - hence international - circuit, but also on a national less visible circuit. It does matter whether a theory emerges in a low-circulation culture and language or in an international language, just as it does matter whether it emerges in a "monolinguistic", "plurilinguistic", or postcolonial society: the "pressure" of assimilating or adjusting to the influences from the "centre" changes considerably.

[Translated by Alina Piftor]

\section{Bibliography}

Argintescu-Amza, N. (1965). Despre «Frumoasele credincioase», in „Secolul XX”, nr. 2.

Baillargeon, J.-P. (ed.) (2002). The Handing Down of Culture, Smaller Societies and Globalization, Presses de l'Université de Laval.

Baker, M. (ed.) (2000). Routledge Encyclopedia of Translation Studies, Routledge, New York, ed. I, 1998.

Baker, M. \& van Doorslaer, L. (ed.) (2000). Routledge Encyclopedia of Translation Studies, Routledge, New York, ed. I, 1998.

Baker, M. \& Saldanha, G. (ed.) (2011). Routledge Encyclopedia of Translation Studies, Routledge, New York, ed. II, 2009, CrossRef.

Balaci, Al. (1981). Colocviul național de traduceri și literatură universală, in VR 1981, p. 74.

Berner, Chr. \& Milliaressi, T. (ed.) (2011). La traduction: philosophie et tradition. Interpréter/traduire, Presses Universitaires du Septentrion, Villeneuve d'Ascq.

\footnotetext{
${ }^{11}$ Precisely the variations within the semantic sphere of the term "translation" in the great and less great cultures of the world, which he examines, emphasize on the close connection between a cultural space and the way in which translation activity is viewed in various moments throughout history.
} 
Blaga, L. (1957). Cum am tradus pe Faust, in „Steaua”, nr. 8, 5 mai.

Breslașu, M. (1965). Probleme teoretice ale traducerii: pe marginea unei cărțti de Georges Mounin, in „Secolul XX”, nr. 1.

Busuioceanu, O. (1981). Colocviul național de traduceri și literatură universală, in VR 1981, p. 62.

Cassian, N. (1973). Arta de a traduce, in „Secolul XX”, nr. 1, p. 146-148.

CREL 1983 = „Cahiers roumains d'études littéraires”, nr. 1, Poḯtique/Poétique de la traduction, Univers, București, 1983.

Covaci, A. (1981). Colocviul național de traduceri și literatură universală, in VR 1981, p. 14.

Cronin, M. (2003). Translation and Globalization, Routledge, New York.

Derrida, J. (1998). Psyché. Inventions de l'autre, in Des Tours de Babel, Galilée, Paris.

Doinas,, Șt.-A. (1965). Dificil, riscant, dar nu imposibil, in „Secolul XX”, nr. 2, p. 164-168.

van Doorslaer, L. \& Flynn, P. (ed.) (2013). Eurocentrism in Translation Studies, John Benjamins, Amsterdam, CrossRef.

Eliade, I. (1981). Colocviul național de traduceri şi literatură universală, in VR 1981, p. 94.

Flynn, P. (2013b). How Eurocentric is Europe? Examining scholars' and translators' contributions to translation studies - an ethnographic perspective, in van Doorslaer \& Flynn (2013), p. 62-77.

Gambier, Y. \& van Doorslaer, L. (eds.) (2012). Handbook of Translation Studies, vol. 3, John Benjamins, Amsterdam, CrossRef. Gambier, Y. \& van Doorslaer, L. (eds.) (2013). Handbook of Translation Studies, vol. 4, John Benjamins, Amsterdam, CrossRef. Gentzler, E. (2013). Macro- and micro-turns in translation studies, in van Doorslaer \& Flynn (2013), p. 9-28.

Gile, D. (2012). Institutionalization of Translation Studies, in Gambier \& van Doorslaer (2012), CrossRef.

Hermans, T. (ed.) (2002). Crosscultural Transgressions. Research Models in Translation Studies. II. Historical and Ideological Issues, Routledge, New York, CrossRef.

Hermans, T. (2014). Translating Others, vol. 1, 2006, vol. 2, 2012, Routledge, New York; ed. I, St. Jerome Publishing, 2006.

Ionescu, G. (1981a). Orizontul traducerii, Univers, București.

Ionescu, G. (1981b). Colocviul național de traduceri și literatură universală, in VR 1981, p. 89.

Ivanovici, V. (1983). Text and Translatability, in CREL 1983, p. 11.

Jacquier, H. (1965). Babel, mit viu, in „Secolul XX”, nr. 1, 1965, p. 151-160.

Kohn, I. (1983). Virtuțile compensatorii ale limbii române in traducere, Facla, Timișoara.

Kohn, J. (1998). Romanian Tradition, in Baker \& van Doorslaer (2000), p. 539-541.

Lăzărescu, G. (1981). Colocviul național de traduceri și literatură universală, in VR 1981, p. 94.

Levițchi, L. (1981). Colocviul național de traduceri și literatură universală, in VR 1981, p. 54-55.

Londei, D. \& Callari Galli, M. (ed.) (2011). Traduire les savoirs, Peter Lang, Berna.

Lungu Badea, G. (2013). Idei și metaidei traductive românești (secolele XVI-XXI), Editura Eurostampa, Timișoara.

Matei, Al. (2014). Fîntîna barthesiană. Cazul Henri Jacquier și două păcate mortale, in „Observator cultural”, nr. 719.

Mavrodin, I. (1983). „La traduction - une pratico-théorie”, in CREL 1983.

Munteanu, R. (1981). Colocviul național de traduceri și literatură universală, in VR 1981, p. 60.

Oustinoff, M. (2011). Traduire et communiquer à l'heure de la mondialisation, CNRS Editions, Paris.

Popa, I. (2013). Communism and Translation Studies, in Gambier \& van Doorslaer (2013), CrossRef.

Pop-Corniș, M. (1983). Romanian Poetry in an Age of Translation, in CREL 1983, p. 34-41.

Porumbacu, V. (1951). Tălmăcindu-lpe Scipaciov, in „Viața românească”, nr. 4, 7 iulie, p. 198-216.

Pym, A., Schlesinger, M. \& Simeoni, D. (2008). Beyond Descriptive Translation Studies: Investigation in Homage to Gideon Toury, John Benjamins, Amsterdam, CrossRef.

Ralea, C. (1981). Colocviul național de traduceri și literatură universală, in VR 1981, p. 86.

Sapiro, G. (ed.), Traduire la littérature et les sciences humaines. Conditions et obstacles, Ministère de la Culture et de la Communication, Paris.

Sapiro, G., Editorial policy and translation, in Gambier \& van Doorslaer (2012), CrossRef.

Storch, F. (1981). Colocviul național de traduceri și literatură universală, in VR 1981, p. 72.

Șerban, G. (2011). Meandrele memoriei. Breslașu vs Bresliska, in „Observator cultural”, nr. 560, ianuarie.

Todorov, Tz. (1982). Comprendre une culture: du dehors/du dedans, in „Extrême Orient”, Paris.

Verzea, I. (1981). Colocviul național de traduceri și literatură universală, in VR 1981, p. 50.

Vianu, T. (1956). Ceva despre arta traducerii, in Literatura universală şi literatură națională, ESPLA, p. 267-278.

VR 1981 = „Viața Românească”, număr special, Colocviul național de traduceri și literatură universală, revistă editată de Uniunea scriitorilor, București, 1981.

Vultur, M. (2002). Cultural Globalization ans Smaller Eastern European Societies, in: Baillargeon, J.-P. (ed.), The Handing Down of Culture, Smaller Societies, and Globalization, Presses de l'Université de Laval, p. 192-199.

Wolton, D. (2003). L'autre mondialisation, Flammarion, Paris (apud Oustinoff, 2011). 